\title{
Democratic Design for the Humanization of Education
}

\author{
Stephen Lafer, Ph.D. \\ University of Nevada, Reno, USA
}

\begin{abstract}
The purpose of this paper is to continue the development of a deep definition for democracy and to consider the implications for educators who teach to that deep definition. Democracy demands much from its citizens in regard to their ability to acquire knowledge of value and make sense of the meanings inherent in that knowledge, this for the sake of participation in the decision-making processes that are the hallmark of true democracy. Many societies that claim to be democracies are, at best, something less than true democracies and, to a large extent, this is due to the failings of their educational systems, systems that are remiss in helping their students learn to think well for themselves. The reasons why this is so are discussed and a call for the reinvention of educational systems is made.
\end{abstract}

Keywords: Democratic design, humanization, society, and true democracy

\section{Introduction}

For most of my career as an educator, a teacher and a teacher of teachers, I have spent considerable time trying to discover foundational principles to guide my thinking about the work and the value of what I was teaching to my students, their students, and the society in which we live. I taught for quite a long time without such principles in place but, somehow, I did have a sense of wrong and right, of what results were meaningful and somehow right results and of methods that had the effect of moving students closer to these results. Certainly I got it wrong on occasion, but something I knew implicitly allowed me to recognize error and seek out the correctives. For the good educator, time spent on getting it right is critical because it is the humane thing to do. Getting it wrong can do considerable and lasting damage to human beings.

The humane thing, I have come to realize, is the thing and the humanity of the actions I take as an educator is and always has been the criterion against which I have made determinations of right and wrong action as a teacher. The humanity of the work is the marker for the righteousness of the work and concern for the righteousness of acts of instruction is vital to good teaching and the democratic society.

Righteousness, goodness, effectiveness in teaching in the current era acquire proper meaning, their validity, only in their relationship to democratic imperatives, this because democracy is the most humane ordering of beings, individual human beings, when they must live amongst one another. Democracy exists to preserve the rights that allow one to be human, to be and grow as an individual who possesses those attributes that make one human, most important amongst these, the right, as the framers of the Declaration of Independence argued, to life and liberty and to pursue happiness.

Educational programs that serve democracy are obligated to help students grow as selves capable of living as citizens of the democracy and, what it means to be a citizen of a democracy is something every good teacher needs to try to understand. I say "try" because it is the life's work of an individual in a democracy to constantly make determinations as to what constitutes proper action as a citizen. Democracy, as a social order, provides no specific rules of order; it is the citizens of democracies who determine the rules, the laws that they will allow to encroach on freedoms that are theirs by virtue of their being human, freedoms unalienable because they are of nature's law, rights that any truly thoughtful individual being will understand to be vital to meaningful existence as a human being.

The writers of the Declaration of Independence, the single most important statement of both the meaning of and the moral necessity for societies built on democratic principles, wrote from heart. They developed their principles of the decent human life, the life that good societies serve, on the basis of their understanding of the lives they lived and contemplation of what it was in life that allowed them to live as human beings in touch with their own humanity. They engaged in the process of realizing their potential as beings possessed of the capabilities and capacities nature provides those in possession of the qualities that are human qualities. From life they derived their principles of democracy.

Amongst those qualities, the most important of qualities, they recognized, is the ability to think as a human being, as an individual engaged as an intellect in the world, an intellect who is in the world and who can use his or her intelligence to make sense of the world, sense made providing reason 
for actions upon the world. To live in a society, amongst others, in human societies in which those others possess both the abilities and the rights that are human abilities and human rights, in order for there to be a peace that costs the least in terms of limitations on rights, citizens of democracies agree to be regulated by laws by which they agree to be bound, agreement predicated on the fact that individuals impose these laws upon themselves for the sake of peace, peace being amongst the conditions that allows a person to enjoy freedom.

The law making processes of democracies are at is core, and it is through participation in making the laws that citizens maintain their freedom, in the decision making processes that produce laws that sustain democratic society. If proper citizens, their decisions are properly democratic; they are ultimately humane, reflecting high levels of empathetic spirit, a sense of other in self and self in other, knowledge of mutuality in being, in being human. Such a mindset allows for societal decision making processes that produce laws that are just and equitable. Within the context of true democracy, individuals are completely free and they are free to enjoy their independence, to exercise their individuality. This freedom is tempered by choice and only by choice, the law existing as a binding agreement that reflects the will of the people, free individuals, to place limitations on themselves to protect the civility that allows them to live freely amongst other free beings.

Schools for democratic societies, the public schools, exist to serve democracy. Primarily, their role is to provide students the education necessary for proper participation in the democratic process and to this end they help students acquire the tools and the sensibilities critical to effective citizenship. In regard to sensibilities, most important are those that allow one to take advantage of freedom, to think as an independent being capable of original thought, able (and willing) to bring to bear on the societal decision making the product of thought. Democracy, for it to exist, necessitates participation on the part of all who are citizens and, to result in goodness, all who participate must be thoughtful, well informed, and articulate.

For a people to be willing to engage in and provide for democracy, they must understand and hold an abiding belief in the benefits of democracy. Without such there is little likelihood that they will do the work of democracy, commit to engagement in the democratic process. Without the participation of the people, democracy cannot exist for it is participation in the decision-making processes of the society that makes a society democratic. Schools in and of democracies, then, besides aiding students in developing skills and acquiring knowledge, must help students to understand the importance of democracy, what it offers that make it so worthwhile. They have to understand that, as Dewey (1937) tells us, democratic societies are the best type of political arrangement human beings have yet devised, best because democracies allow humans to live free while living amongst other free human beings. They are the most humane form of social organization because they provide people the opportunity to live humanely. Students not only have to know of what it is that democracy provides and allows, they have to develop a love for democracy that reflects deep understanding of its benefits.

Democracy, according to Dewey, "is a means, the best means so far found, for realizing ends that lie in the wide domain of human relationships and the development of human personality" (1937, p. 138 ). To appreciate democracy one must know heartedly of the value of human relationships and the meaning of value in the development of the human personality, the potential within to come to know that which empowers, that which allows one to make things and make things happen and the potential in others to contribute to the process of such enabling growth. This is the golden rule of democracy, the self-evident truth of it when experienced, and it serves as a corrective to tendencies that exist for inhumanity; worth in self and other, self to other and other to self, intellectually speaking, means the world, what it means and what one can do in the world once one possesses understanding.

It may sound trite to say, as it sounds trite now to say that one stands for such things as peace and love, that those properties of democracy that democrats derived from living the lives of free individuals amongst other free individuals, individuals free to think for themselves, are properties that allow for humanity and it is the sense of humanity, of being human and the potential that exists in being human that allows democratic citizens to exercise willful temperance in determining proper law, law that is humane. Thinking influence by authentic democratic imperatives constitutes something intangible but as essential as life and liberty, the spirit of democracy, something that has to exist within members of democratic societies but cannot be taught through direct instruction. Democracy, in forms authentic enough to allow for the democratic life derive only from conceptualizations of being, the understanding that one is singular and original, but also that the one, the self, in being, has implications for others and others for the self.

Freire (2005), who argues strongly for human liberation, for individual freedom, also argues for humanization, and, in one of those incredibly wonderful paradoxes that arise with thoughtfulness, he recognizes that humanization liberates while limiting. One cannot treat another, another known to have the human attributes so critical to self, inhumanely. This is the law rendering basic that makes 
possible the peace between beings that creates space for being the self one is and having sufficient room to express that self.

Democracy, in theory and in the actual force it exerts upon those who are citizens of democracies is paradoxical, offering extreme amounts of freedom for the price of voluntary submission to particular kinds of laws. Democracy exists to preserve freedom. To do so, it demands that freedom be limited, the mind of the democratic citizen free to think of what it will but, with the proviso that a decent amount of the time be spent thinking about others, their thinking, and the affect of one's own on theirs and theirs on one's own. This kind of thinking for self, moderated by empathy, results in critical thought, a most powerful tool for intellectual growth, and is the mindfulness demanded by democracy of its citizens. The constituents of a democracy prize individuality so well as to wish to take good care of their fellows who are dedicated to "the development of the human personality" for this is the key to quality of live and the creation of the better society.

The society, to accommodate the growth of kind of human personality that will serve to move the society toward betterment, must be a dynamic society for it is inevitable that a populace engaged in critical thought will foment change and wonderfully so, the founders of the democratic project that is the United States of America, recognized this and, in creating a constitution for a democracy did so recognizing that their work would result in something more perfect and not yet perfect because the cause of perfection, the desire to move the union toward perfection would have to be the motivating force for democratic behavior. The force that maintains the peace in a democracy cannot be coercive. It must be of the people and it can only be of the people if the people, at any given time in history, are involved the work of democracy, working toward betterment, towards perfection, for the good of self that depends on others to nurture that goodness along.

Freire, who deserves to be cited broadly for his insights into the building of humane societies, argues at one point in Pedagogy of the Oppressed that "both humanization and dehumanization are possibilities for a person as an uncompleted being conscious of their incompletion." This is as powerful a notion as a human being can encounter because it is not only liberating (what is isn't necessarily what can be, what I think I can do isn't necessarily all I can do), but also humbling and cause for a kind of empathy we, as human beings, have yet to fully recognize, this conceptualization taking into consideration potential, latent potential that liberates the future from the possible as it is conceived of in the now. What capacities the human mind? We cannot know. What affect the unknown capacities for mindfulness and there effect upon the world? We cannot know. And this for humans and individuals and human beings in and upon societies! There has never been nor never will be a moment when life as a human being is dull and this realization needs to be something that any school dedicated to democracy must help its students to achieve.

In being incomplete, with the capacity to know of one's incompletion and having the drive to grow toward completion, human beings, by nature, have choice and, in matters of human existence, the choice to become a more human being. For one who has understanding of what it means to be a human being, a person aware of incompleteness and of potential, this coupled with empathy-the understanding that others who are human are human like oneself-understands that the sensible path is toward humanity. The choice to become something less than human is available, and one must choose so to deny others their humanity. Dehumanization of others, denial of worth and potential worth if given opportunity, for a human being aware of his or her own incompletion and potential for human growth and development, is inescapably unconscionable.

In bringing to consciousness the notion of "uncompleted being conscious of their incompletion" Freire offers up for humanity legitimization of nothing less than hope, this predicated on the realization that with potential to become something more than, something better than what is now, with knowledge of incompletion as a self-evident truth, incomplete in our understanding of things and, therefore, unable to at any given moment in time know the possibilities that are available to us in our world, in the universe in which we live we, as human beings, truly are free. The choice to oppress, to deny any the opportunity to be free, to think freely, has to be understood by the individual in the process of realizing his or her human potential to be an intolerable affront to humanity.

Hope, viable and almost tangible as a property of existence, is communicated ever so succinctly in the Preamble to the Constitution of the United States of America. The purpose of the government the Constitution will put in place is to "create a more perfect union." The choice of modification, of insertion of the word "more" strongly implies that something better is a viable possibility, thus, hope, is established as reason for the shape the new government will take, the laws proscribed by the Constitution the best laws the framers can produce to allow human beings their freedom to move themselves toward their potential, toward betterment as human beings so that they can make for themselves better lives. 
The potential of human beings to make choices that can and do have the effect of bettering the conditions of life and the quality of life and the opportunity being human provides for one to know of this potential lends value to being to the extent that life is always worthwhile and, that this is so is something that schools consistently fail to help students understand. Incompletion, the realization of incompletion, is a force, perhaps the most important force driving meaningful human existence because it constantly pushes a being to do what humans, uniquely, can do and that is think like humans to know about self in the world in ways that allow for acts in and upon the world that do change the conditions of life.

Thought is of consequence. This is understood implicitly by those aware of incompletion and potential, the potential of thought to affect the world. With this understanding comes vigilance in the thought processes that guide decision- making for those who are aware of their efficacy, of their own potential to affect reality. Without such sensibility, one cannot understand that his or her thinking is of any more consequence than penciling in the "correct" bubble on a standardized test. In a sense, the choices that most schools present students are of so little consequence that vigilance in choice making is non-existent. Kenneth Howe, invoking the work of Amy Gutman, makes the case that in schools that teach for democracy, what is important is not that students make the choice the authorities consider to be the "right" choice, but that students are able to "deliberate effectively" (Howe, p. 459).

Learning to "deliberate effectively," for Howe and for Gutman, is the primary purpose of schools that serve democracy. Effective deliberation serves that aspect of human freedom most basic to freedom and to democracy, the ability to make choices. Human beings are capable, most certainly, of making bad choices, choices that make things worse rather than better. Freire, for example, tells us that humanization and dehumanization are real alternatives" and this should be taken for what it is worth, that choice, failure to chose sanely and righteously can and does lead to destructive ends, for individuals and for human societies. He also notes that there is concrete proof, across the span of history, to show that dehumanization has upon many occasion been the choice, this leading to the oppression of a great many people.

While dehumanization is possible, he writes, "only the first is the people's vocation," and what is truly hopeful about this is that he is right. He is right because human beings, as individuals and as societies, when their actions dehumanize either deny the actions or the effect or apologize for the results. It is extremely rare to find an individual or a society that prides itself in being the cause of dehumanization and the effects it has on the affected human beings.

The central purpose of education for citizens of democracy is to help individuals develop their understanding of their individuality and the meaning of individuality in regard to both self and others. This, it needs be said, is very much a contested concept in those societies today that call themselves democracies. In such places, even when the laws of the democracy grant individuals considerable freedom to be the individuals they are, forces of culture, religion, and nationalism intertwined with a sorry sense of patriotism, work against the individual becoming who he or she can and would be. These forces undermine the possibility of democracy and, when they are allowed to influence and interfere with education, the possibility of democracy is, too, undermined.

Democracy, as a form of social organization, organizes for the benefit of the individual. Democracy is about governance that is humane and that that is humane is that that allows the individual to be him or her self, to become him or her self and not something else that someone wishes the individual to be. Democracies exist for the wellbeing of the individual and, thus, can never exist for sake of the society itself or for the sake of any particular ideology, religion, or set of beliefs. Societies that demand of individuals that they serve the state are not democratic societies unless individuals understand the state to exist fort heir best interests. A nation that demands of citizens that they serve the state is not a democratic state. A nation, a nation democratic enough to do so, teaches its citizens in such a way that they serve the state willingly because it is a state that serves them, as individuals, and it demands nothing of the citizen such as allegiance or even citizenship. It does not need to because the properly democratic state is of the people; it is their state and they do what is necessary to preserve the state because it serves them well.

The state that demands or commands loyalty and allegiance, that forces or coerces individuals to serve it is not a democratic state. A people aware of the goodness of the state, good in that it serves their needs, needs not to command or coerce. And its educational system can help its students to acquire the tools necessary for making good decisions, for making sensible choices for self and for society. A society that demands the service of its people is a society that is about state and not its people and a state that commands its people to uphold state is a static state and, therefore not a state that respects individuality and the proper right of individuals to make choices for themselves. It teaches citizens what their aspirations should and must be whereas the truly democratic state is a dynamic state that changes with the will of its people, to serve their best interests. 
This is the ideal, state in its democratic perfection, a state of state that has never yet been realized but which, in the sensibilities of true democrats, is the goal of any initiative they can approve for the state to institute. Education serves the state of mind that produces such institutions and guides their adjustment and modification so that they work in the service of the people, to provide what is essential to insuring them their natural rights and freedom.

As Freire noted, people, free people with freedom of choice, can choose to create institutions, amongst these laws, that serve to dehumanize. However, he argues, that this is not the vocation of the people and he knows this because he knows what it means to be human; he has come to achieve, through thought, his humanity, understanding of what it means to be human. He works, as a teacher, to help others discover what he has discovered about human beings and, in doing this he reveals, to self and others, more of what it means to be human. He, as a human, engaged in the work of completing his self and, because his work is properly focused on what is humane, constantly struggles to better understand self and world to better understand the meaning of self in the world. A good part of this has to be about the proper role of individual in society and the nature of the humane state.

Dewey tells us that democracy, to date, is the most human form of state yet devised by human kind, he, as does Frere, recognizing incompleteness and its recognition as vital to the human understanding of what is real. And so too do the founders of the American democracy who admit to nothing more than the "more perfect union," this leaving open the possibly that, over generations, beings engaged in the human vocation of humanization might discover something more perfect, something even better than democracy. A more perfect form of social organization. For a society to be fully and freely engaged in the work of perfecting itself, it cannot be so much concerned with preserving the state as to prevent its reinvention.

Human beings, in democracies, shape the state they allow to interfere with their freedom and, thus, "The key-note of democracy as a way of life may be expressed," says Dewey,

....as the necessity for the participation of every mature human being in formation of values that regulates the living of men together: which is necessary from the standpoint of both the general social welfare and the development of beings as human (1937, p. 217).

Democracy is about rules and laws that regulate the lives of citizens but the rules and laws are not what democracy is. The rules and laws of democracy exist to enable, exist as understandings amongst the people, attitudes in highly realized forms of democracy, that allow individuals to co-exist freely. Dewey fully recognizes that democracy is something other than a type of government. He makes this clear by saying that,

Universal suffrage, recurring elections, responsibility of those who are in political power to the voters, and the other factors of democratic government are means that have been found expedient for realizing democracy as the truly human way of living. They are not a final end and a final value. They are to be judged on the basis of their contribution to end. It is a form of idolatry to erect means into the end which they serve (Dewey, 1937, p. 218).

If a democratic society is to exist as a true democracy, then the opinions of its citizens must be heard, not as auditory buzz, but for the substance of what is being expressed. Thus, one of the salient goals of education for democratic society is that students learn to properly respect the opinions of others. Such respect is mentioned directly in the Declaration of Independence where it is argued that lack of respect for the opinions of men is sound reason for overthrowing a government. "Respect," does not mean to accept uncritically, Dewey offering the poignant caveat, that opinions, however formulated, however conveyed "are to be judged on the basis of their contribution to end," the legitimizing of ends having to do with showing that opinions rendered reflect "both the general social welfare and the full development of human beings as individuals."

For educators this is prescription, the prescription, that educational programs serving viable democracies and viable democratic aspirations need to help students acquire what it is that is necessary to develop opinions that contribute to proper decision making in societies that exist to serve the "general social welfare and the full development of human beings as individuals. Schools, to be meaningfully productive then, must help students develop a sense of the role of individual in society and the role of society in meeting properly humane ends. They work toward the full development of individuals in their humanity and the effective participation of such individuals in moving the society toward perfection. Such teachers concern students with the propriety of opinions offered, decisions made, and actions taken in regard to their value for making the conditions for human existence ever better, ever more appropriate for growth and development of what is human.

Sadly, I have not yet seen the democratically appropriate school and I do not know of a society that cares to build such schools. For this reason, I know of no society that has come close to being a democratic society. The schools in the nations I have visited, the nations that proclaim democratic aspirations, the best of them, as a matter of policy, prepare students to be well adjusted 
members of the society, individuals who will behave in such ways as to serve the aspirations of the leaders of the nation citizens who will not complain about not being invited to participate in the processes by which policy is developed and decisions are made or, just as importantly those concerning the role of individual citizens in determining what the aspirations of a nation should be. At best, in present day "democracies," individuals are trained in schools to serve the nation but rarely are called upon to think about what nation perfected might look like and what purposes such a nation would serve. They serve stasis and not the dynamism a properly democratic society relishes.

In the schools I have encountered, these schools in in nations that profess to be democratic nations, curriculum and methods are set, often by the state, and never through a process reflective of the democratic imperative that demands that those governed-and in schools people are governedhave a voice in how they are governed. This is not to say that schools must be places where student make the rules. It is to say that they should have a voice, that their opinions be treated with respect, respect here meaning that their opinions are heard and discussed. In such schools, discussion of opinions - call them understandings, is the primary means of instruction. This is the problem-solving method, a method based in meaningful and meaning-making dialect.

Within any meaningful dialectic, of course, maturity is always a valid concern in determining the true meaning and value of opinions rendered. Thus, in the course of sensible decision-making process maturity is a factor that the sensible consider. Sensible consideration of maturity does involve age, and chronological age does sometimes provide useful information. Sensible individuals have reason to trust that opinions, perspectives offered by the very young, are apt to be less grounded in knowledge and experience than those of older individuals. However, the pervasive attitude, the attitude pervasive in educational institutions, is that because the young are young and without experience and knowledge, education should be about wiser adults passing on their wisdom to the young who are without wisdom.

I do see the logic and it does make some sense, that there is value in considering the age and maturity of a thinker in considering the the value of his or her ideas. However, this logic, particularly when it is applied to make determinations regarding instructional methods, is a flawed logic that leads to a crippling kind of disenfranchisement and to educational practices that interfere with and often undermine meaningful human growth and development. The concern for maturity far too often leads to instruction that is of the type that Freire refers to as the "banking method;" the teacher who assumes to know passes knowledge on to those knowing naught. What is lacking in those who opt for the banking approach is a mature understanding of what it means to know and, too, what constitutes proper understanding. Ultimately, these educators fail to reflect on the quality of the learning their methods produce and its real value for the growth and development of human beings as thinkers, as a thinkers who are human because they think.

That schools do not really care about what students think is patently obvious in the kind of assessments so often used in schools systems that have adopted the modern methods, amongst the textbook driven curricula and the use of standardized tests on which a single answer is the correct answer no matter what an individual's real thought and opinion on the matters being addressed test might be. A student can be deemed educated by virtue of success on a test that never asks him or her to explain the understanding the individual holds or to offer an opinion that would help those concerned with the learning to understand what quality of learning has been achieved by the individual being tested.

There are many other symptoms that support the conclusion that education, as it is offered in most places now, is more an illness than a remedy, at least in regards to its effect on the creation and perpetuation of viable democratic societies. As a result, modern democracies are not true democracies because their real goals have little to do with providing the kind of freedoms that allow individuals to grow in their individually, to become the original thinkers they are born to be. The people, citizens do not know what to demand of the society or how to go about making their understandings and opinions meaningful in the context of the societal decision making process. Freire tell us that "education is suffering from narration sickness." He says that,

The teacher talks about reality as if it were motionless, static, compartmentalized, and predictable. Or else he expounds on a topic completely alien to the existential experience of the students. His task is to "fill" the students with the contents of his narration-contents which are detached from reality, disconnected from the totality that engendered them and could give them significance. Words emptied of their concreteness and become a hollow, alienated, and alienating verbosity. (Freire, p. 71)

He goes on to say that,

Narration (with the teacher as narrator) leads students to memorize mechanically the narrated content. Worse yet, it turns them into "containers," into "receptacles" to be "filled " by the 
teacher. The more completely he fills the receptacles, the better teacher he is. The more meekly the receptacles permit themselves to be filled, the better students they are (Freire, p.72-73).

He then makes this stunning statement, that "any situation in which some individuals prevent others from engaging in the process of inquiry is one of violence;... to alienate humans from their own decision making is to change them into objects."

These are the practices used in the schools of which I know and so too, the results of practice. The schools force educators to become perpetrators of this violence, violence that most definitely affects individuals and, as importantly, a type of violence that works against humanity, against the potential for human beings to become humane individuals, individuals who find dignity in being human and adverse to destroying other human beings because of their profound understanding of what it means to be human.

I have just described what it is that is most basic to democracy and why, as a form of government, democracy is basic to the growth of human beings as individuals and as members of societies. So much of what is necessary for growth and development is understanding of the nature of our being, of our capacities, of aspects of knowledge that must be discovered by each person through inquiries into the meanings of things that give meaning to life. Through such engagement, one grows as an individual and this growth allows for ever more valuable contributions to the development of societies that are truly humane.

I have not here offered a particular methodology, only a theoretical framework that has been offered many times before by those who have studied democracy to discover its true meaning as a form social organization and a force in governing men and woman for the sake of the orderly conduct of the affairs of state. Indeed, democracy has much to do with order and lawful conduct that allows order to exist. On the other hand, because order has been so much the focus of governance, the purpose of good order has been forgotten, that being, in the good society, in the democratic enough order to allow all to be as free as is humanly possible when human individuals live amongst others who are also human.

Because to be human is to think and to think is to reorder, democracy necessitates a type of order that is extremely difficult to define in concrete terms. But that is no problem, really, because democracy isn't about building things out of concrete to last forever. It is about ways of thinking that allow human beings to understand what is good and what is better and continue on the path toward the better, the desire for perfection always somewhere alive and driving mindfulness.

There are ways to educate that open minds rather than convince their owners to shut them down, to be quiet and listen. The purpose of this paper is not to enumerate the methods but, in the name of methods. suffice it to say that serious consideration of democracy as it is explained here and strong desire to do nothing educational that can do harm to the democratic citizen's humanity, to his or her human spirit, will bring about better results than a book filled with fail-proof methods for teachers to carry out with little of their own mindfulness in the mix.

Only thoughtful teachers who understand the relationship of thoughtfulness to being and becoming more human (and this can only be known by experience thoughtfulness and its humanizing effects) can one teach well to democratic imperatives. Lastly, there are many ideas for translating the theory offered here into practice and I direct readers to the Core Curriculum State Standards for mathematics and English language arts introduced recently in the United States, these along with the Next Generation Science Standards also recently published in the United States. These standards begin to suggest methodology but always with the explanation of how things need to be known and not only what needs to be known. Too, a number of posts on this author's blog site, lafered.com, extend the discussion here into the realm of practical application of theory.

\section{References}

Common Core State Standards Initiative: Preparing America's students for success. (n.d.). Retrieved November 14, 2014, from http://www.corestandards.org/

Democracy and Educational Administration. (2008). In J. Boyston (Ed.), John Dewey: The Later Works, 1925-1937 (Vol. 11, pp. 217-220). Carbondale, IL: Southern Illinois University.

Freire, P. (2005). Pedagogy of the Oppressed. New York: Continuum.

Gutman, A. (1999). Democratic education. Princeton, N.J.: Princeton University Press.

Howe, K. (1992). Liberal Democracy, Equal Educational Opportunity, and the Challenge of Multiculturalism. American Educational Research Journal, 29(3), 455-470.

The Next Generation Science Standards | Next Generation Science Standards. (n.d.). Retrieved November 14, 2014, from http://www.nextgenscience.org/next-generation-science-standards. 